\title{
I now take care of myself and am no longer a drug user
}

\author{
Germaine Muhorakeye
}

My name is Germaine Muhorakeye. I was born in 1971, in the Western Province. I now live in Bugesera District, where I moved shortly after the genocide. My mother was a housewife and my father an agriculturalist. My father died when I was still young, but his pension allowance continued to help my mother to raise us. We were seven children in my family; three sisters and four brothers. We lived among cows and coffee and banana plantations. Our grandfather also supported our mother. My good memories from before the genocide, when I was still young, are of family meetings and sharing New Year parties at our house. We used to share good meals, cook, and prepare the drinks for New Year parties together. These were my happiest moments, which I will never have back.

I got married in 1992, but my husband was killed during the genocide, after only two years of marriage. Among my siblings who were in Rwanda during the genocide, I am the only one who survived. Almost all of my family members were killed during the genocide, and I myself was abused. My two brothers who are still alive were in the former Zaire (now Democratic Republic of Congo) at the time. I met them again in 1998. The genocide found me in the former Kibuye Province.

At the beginning of the genocide, my husband and I went to my parents-in-law. When we reached their place, my mother-inlaw said that she would only receive her son. She told him that if he wanted to survive he should stay alone with her because she could not hide me. My husband replied that he could not leave me alone. I was carrying our firstborn on my back. We left and started to search for a place to hide. We eventually hid in the bush near our house. When the genocide got worse, we ran away separately. To this day, I do not know where my husband was killed.

I hid in the bush together with my daughter and other women I had met on the way until a group of killers caught us. With the help of dogs, these Interahamwe were hunting people down to kill them. After they caught us, they took us out of the bushes and onto the grass, raped us, and left us lying there. After a while I felt thirsty and went to look for water. Unfortunately, one Interahamwe saw me, used a rope to pull me towards a hole, and threw me into it. I spent three days in this hole. People say that hunger kills. I experienced that it does not. After a few days, the killers came to bury the dead bodies of people they had killed on top of me, because they had started to smell bad. When I heard the Interahamwe say that they had to close the hole, I tried to get out and eventually succeeded. I quickly decided to leave the place, because if they would come back, they would put me back in the hole.

I then decided that I would drown myself in Lake Kivu, but because I was scared I went back to the bush instead. On the way toward the bush, I met Congolese men who were passing through with looted electronic materials. I also met two other young girls who planned to cross the lake in the direction of Congo. The Congolese men, who 
were also behaving like Interahamwe, told us that if we had money they would help us cross the lake and take us with them into Congo. The other girls did have some money and gave it to them. By chance, when we arrived in Congo, I immediately met my uncles who had taken refuge there in 1959, but I did not join them. I lived with other Rwandese in the small houses which had just been built for 1994 genocide refugees from Rwanda. After a few weeks, the RPF soldiers who were in Congo helped us reach the nearby hospital in Bukavu. Because medical care in Bukavu was poor, the RPA members then took us to Burundi, where we were treated. I could not move because of the rape and injuries to my legs. My health state was critical.

When the genocide was over, we came back to Rwanda; we went to the district of Ngoma in the Eastern Province. After two weeks, myself and other people who knew how to read and write were recruited by Médecins sans Frontières (MSF). MSF brought us to Bugesera, where I began to work as an assistant nurse. It turned out that I was pregnant from the rapes I had experienced during the genocide. I was bleeding, but attributed that to the gang rape. Because of my poor health condition, I spontaneously miscarried in October 1994. After recovering, I continued working at the surgical ward of the nearby health centre. This is where I met my future second husband. He was hospitalized there for injuries due to genocide grenades. I was depressed and I hated all men. I had decided to never marry again because I considered all men to be vicious.

While I was still depressed, without hope for the future, my firstborn was stolen from me by my sister-in-law. This was the second woe after the rape. My sister-in-law took my daughter when I was at my work. Back home, after noticing that the child was not around, I tried to search everywhere, but I did not find her. After a long time, I heard from a cousin of my first husband that the sister-in-law had taken my daughter to America. What makes me sad is that I do not even remember the face of my firstborn. Those two events killed me. I felt that I was alive without being alive. My heart was full of hate and deep hopelessness.

The man I had met at the health centre kept insisting that I marry him. We both were genocide widow(er)s; he had lost his wife and his eight children. Because he continued to ask for my hand, I had the courage to tell him that I had been raped. I told him that expecting that he would feel discouraged and not want to see me again. I was not interested in men because being raped is not something simple. He was not discouraged and succeeded in convincing me. He said, "If you do not want to sleep in a room with me, come and live in my house until you die". We married in August 1995.

I continued to suffer from the consequences of rape, especially when I was pregnant. I bled for many years until doctors decided to remove my uterus. Throughout the six years that I lived with him, my second husband showed his love for me. Unfortunately, in 2001, he was assassinated on his way back from the elections of Gacaca judges. The people who killed him must have been afraid of his future judgements. He died just as I had learned that both of us were HIV positive as a result of the rapes. Luckily, my seven children are HIV negative.

After the death of my husband, I experienced ihahamuka. I wanted to kill myself. During the mourning period I was capable of losing my clothes and not remembering where I lost them. His death traumatized me severely, because he had become my only hope. I had put my life in 
his hands. After his death, I used to go hide in the house. I lost my appetite and could not eat. I stopped talking to my children. I started to forget to take my antiretroviral treatment. I was often feeling very lonely. I often went to bed and cried because of the grief. I started drinking kanyanga, thinking that it could help me to forget my bad experiences. Out of desperation I became a real drug user.

Because my husband was rich, I never approached organizations that were supporting genocide survivors in order to seek assistance. I had cows left by my husband. My brothers helped me to get medical care. As I became more vulnerable, the church I belong to enrolled one of my children on the list of children supported by Compassion International. They are now paying school fees for this one child. Moreover, I have small houses inherited from my husband, which I rent out. This gives me the means to nourish my children and pay their school fees. I do not cultivate because I am not able to do that. That is why I decided to continue with my studies so that later I can find a good job.

As I continued to suffer from trauma, a cousin of my second husband was always there for me. In 2011, she invited me to join a sociotherapy programme. Before accepting, I asked her what sociotherapy would help me with. She encouraged me to come and see, assuring me that it would help me to feel free. The first time I went I did not attach much importance to what she told me, but after some time I did experience what she had promised. I felt free. When she invited me, I had expected an organization that supports people with material aid. Afterwards, I realised that it was not what I had expected, but that it was another kind of support: moral support.

Sociotherapy allowed me to speak out about my problems to others. Before joining sociotherapy, I could not speak with anyone about the problems I experienced. I hated people. While I was sharing with other women the trauma from which I suffered, the grief related to the death of my husband, and the HIV/AIDS I live with, everybody was listening to me. Sociotherapy helped me accept myself and take care of myself. Since then I have no more ihahamuka. Participating in the sociotherapy programme also helped me tell my problems to my eight children. They started to understand me.

I now live with eight children. Six children are my own, and two are nieces, children of my brothers killed during the genocide. I adopted them. The last two of my children were born due to the influence of drugs (kanyanga). The father of these two children did not support me in taking care of them. After joining sociotherapy, I stopped contact with this man. I now regret what happened. But because of the bad experiences I had endured, my life made no sense to me. I was like a street child. I regained my mind after my husband's cousin, who had invited me to join sociotherapy, started to visit and advise me.

What I liked about sociotherapy is that it helped me meet others and exchange ideas. I gained friends. When I meet sociotherapy group members, I feel free to tell them anything I want and ask for advice. When I am chatting with them, I trust them as I would trust myself. Sociotherapy took away the amnesia I was suffering from and helped me protect myself. I can now approach others and tell them my problems; we then find a solution together. When you share a problem with your peers, the sadness disappears and you realise that you are not alone. The feeling that I can talk freely with my peers is a very crucial thing that I got from sociotherapy.

Because of the support I gained from 
sociotherapy, I expect to finish my studies. After that, I will start looking for a job so that I can plan for my children. I also hope that the job will help me to improve my children's nutrition. Another thing I gained in sociotherapy is the certainty that when a problem is not solved today, it will be solved tomorrow.

Despite the benefits of sociotherapy, poverty makes me fearful. And I did not bring the rapists to justice. The rapists were my former peers at school and my neighbours. They are still alive, but in exile. I only once met a rapist on the street and greeted him, but I was afraid. I had a plan to bring him to the tribunals. Since then, he is exiled and I don't know where he is hiding. However, even now, if I could find the person who raped me, I could not do anything to him. I will forgive him. I will let him go. He might have done the bad things he did because he was encouraged by the government to do so, not because he truly wanted it himself. I cannot bring him to prison; instead, I wish that people who are like him would come forward and apologize.

Even though Gacaca left some unresolved trials behind, it reconciled me with the killer of my mother. My work as a judge in Gacaca helped reduce the hate I had towards the families, including their children, who were involved in the killing of my relatives. Once, what I heard and saw in Gacaca troubled me so much that I could not sit in Gacaca for a month. However, sociotherapy helped me to be patient and continue my role in Gacaca.

As I benefitted so much from sociotherapy, I would advise other women, especially those who have been raped, not to be depressed, because depression is a source of unhappiness for your children. The second thing is to take care of yourself; otherwise nobody else will take care of you. Vulnerable women have to love each other, because this will help them trust others. I would encourage other women to meet in order to exchange advice.

I wish that all women would pass through the steps of sociotherapy. Attending sociotherapy sessions will help them find the strength to talk about their unspeakable experiences. I encourage them because the advice from sociotherapy family members will help them to become respected persons. In addition, I encourage all women to pray to God. 